\title{
Periodic Sorption of Tungstate lons on Anionite AV-17-8
}

\author{
Aleksandr D'yachenko, Roman Kraidenko, Yury Perederin*, Mariya Suprunenko, and Sergey Chegrintsev
}

National Research Tomsk Polytechnic University, Tomsk, Russian Federation

\begin{abstract}
The multiple sorption of sodium tungstate resulting from the autoclave-soda digestion of a tungsten-bearing concentrate was studied using anion-exchange resin AV-17-8. The choice of ion exchange resin was carried out under static conditions using highly basic anionites. The sorption and desorption plots for tungstate and carbonate ions were demonstrated under dynamic conditions. The total dynamic capacity of the resin was estimated for each species of the ions in three sorption cycles. The applicability of the AV17-8 resin as a sorbent in the autoclave-soda process flowsheet was determined.
\end{abstract}

\section{Introduction}

Tungsten is applied in illumination devices, cathode ray tubes, as electrodes, and for the manufacture of highstrength and inert alloys, for example, tungsten carbidebased alloys and tungsten-doped pseudo-alloys, because it is refractory and ductile [1-2]. Tungsten is an essential construction material for the thermonuclear experimental reactor (ITER) [3].Tungsten is also used in mechanical engineering, chemical industry, aviation, medicine, and electrochemical processing [4-5].

The usage of tungsten is growing year after year, and investments are increasingly being made into new tungsten mining projects around the world [6]. However, the tungsten production in Russia does not expand proportionally to the tungsten consumption [7].

The tungsten price per $1 \mathrm{~kg}$ rose from $10 \$(2000)$ to $56 \$$ (2014), which is indicative of the grown demand for tungsten and of insufficient offers [8]. The global tungsten production volumes account for about 25000 tons a year [9].

The primary sources of tungsten are wolframite and scheelite [10]. However, tailings of tungsten-bearing sands are of value as well because improved technologies for beneficiation of low-grade tungsten ores can augment the tungsten output up to a saleable tungsten concentrate [11]. Tungsten can also be recovered from wastes of hard-alloy materials [12].

A lot of tungsten production techniques are currently available. The autoclave-soda digestion [13] and acid leaching [14] are considered to be classical techniques for the processing of tungsten-containing ores. New processing techniques for tungsten-bearing concentrates include the roasting of tungsten-bearing concentrates with silicon oxide in the flowing steam-air mixture to transform them into tungsten trioxide [15]; fluorination process by ammonium bifluoride [16]; and exotic methods for recovering tungsten trioxide, for example, solar production of tungsten trioxide [17].
At this point, among the most common digestion techniques for the concentrate is the autoclave-soda process. One of the stages involved in this process is the ion-exchange extraction of tungstate and carbonate ions [18]. The technology utilizes highly basic anionites in the ion exchange [19].

However, there exist cation-exchange methods for the separation of sodium ions from sodium tungstate [20]. Different instrumentation can also be used in the ion-exchange process: classical passage of the solution through ionite under the influence of gravity and ascendant passage of the solution through ionite under the influence of extraneous forces [21].

Anionites AN-106TP and AN-1TP are of use as the ion-exchange resin for the separation of tungsten and sulfate ions [22]. Trace quantities of niobium, tantalum, tungsten, zirconium, and hafnium can be separated on anionite Dowex 1X8-100 [23].

The main problem of the ion-exchange extraction of tungsten is that ionite must endure as many sorptiondesorption cycles as possible, but in fact the secondary sorption may take place incompletely. Hence, necessity exists to investigate the sorption conditions of tungstate and carbonate ions from solutions after autoclave-soda digestion.

The aim of this work is the tungstate ions selection from the tungsten solution after autoclave-processed soda for further obtaining the tungsten oxide and soda regeneration for its re-use as a leaching agent.

Two tasks have been solved with this goal:

- choosing a suitable anion exchanger;

- checking the anion exchanger under the conditions of repeated sorption.

\section{Experimental part}

Different ion-exchangers were comparatively evaluated for the capability of tungstate and carbonate ions to be sorbed and desorbed from the solution after autoclavesoda digestion. 
The composition of the clarified, concentrated tungsten-containing solution after autoclave-soda digestion is given in Table 1. Tungsten-containing solution was prepared by autoclave-processed soda.

Table 1. Composition of tungsten-containing solution after autoclave digestion.

\begin{tabular}{|c|c|c|c|c|c|c|}
\hline $\begin{array}{c}\text { Compos } \\
\text { ition }\end{array}$ & $\mathbf{C a}$ & $\mathbf{K}$ & $\mathbf{N a}$ & $\mathbf{S i}$ & $\mathbf{W}$ & $\mathbf{C O}_{3}{ }^{2-}$ \\
\hline $\begin{array}{c}\text { Concent } \\
\text { ration, } \\
\mathrm{g} / \mathrm{L}\end{array}$ & 0,07 & 0,16 & 63,65 & 0,13 & 42,95 & 75,50 \\
\hline
\end{tabular}

The following highly basic anionites were used as ion-exchangers: Purolite A-400, A-500, A-600 and Ambersep 920-U, AV-17-8. The anionites were saturated under dynamic conditions with the concentrated tungsten-containing solution in a solid-toliquid ratio of $1: 1$ for $1 \mathrm{~h}$. Desorption was performed with a $2 \mathrm{M}$ ammonium chloride solution in the same solid-to-liquid ratio of $1: 1$ for $1 \mathrm{~h}$.

The tungsten concentration was measured by atomic emission spectrometry and the carbonate-ion concentration by titration [24].

Ambersep 920-U exhibited the highest sorption of tungstate and carbonate ions, but desorption on this desorbent was much worse than on the other resins. Specifications of the used anion-exchange resins are listed in Table 2.

Table 2. Specifications of anion-exchangers.

\begin{tabular}{|c|c|c|c|c|c|c|}
\hline No & Name & $\begin{array}{c}\text { Appearanc } \\
\text { e }\end{array}$ & $\begin{array}{l}\text { Ionic } \\
\text { form }\end{array}$ & $\begin{array}{c}\text { Total } \\
\text { exchange } \\
\text { capacity, } \\
\text { g eq } / \mathbf{d m}^{3}\end{array}$ & $\begin{array}{l}\text { Aver } \\
\text { age } \\
\text { size, } \\
\text { mm }\end{array}$ & $\begin{array}{c}\text { Unif } \\
\text { ormi } \\
\text { ty } \\
\text { facto } \\
r\end{array}$ \\
\hline 1 & $\begin{array}{l}\text { Purolit } \\
\text { e } \\
\text { A- } 400\end{array}$ & $\begin{array}{c}\text { Non- } \\
\text { transparent } \\
\text { spherical } \\
\text { particles }\end{array}$ & Cl- & 0,8 & $\begin{array}{c}0,3- \\
1,2\end{array}$ & 1,6 \\
\hline 2 & $\begin{array}{l}\text { Purolit } \\
\text { e } \\
\text { A-500 }\end{array}$ & $\begin{array}{c}\text { Non- } \\
\text { transparent } \\
\text { spherical } \\
\text { particles }\end{array}$ & Cl- & 0,8 & $\begin{array}{c}0,3- \\
1,2\end{array}$ & 1,6 \\
\hline 3 & $\begin{array}{l}\text { Purolit } \\
\text { e } \\
\text { A- } 600\end{array}$ & $\begin{array}{c}\text { Non- } \\
\text { transparent } \\
\text { spherical } \\
\text { particles }\end{array}$ & Cl- & 1,4 & $\begin{array}{c}0,3- \\
1,2\end{array}$ & 1,7 \\
\hline 4 & $\begin{array}{l}\text { Amber } \\
\text { sep } \\
920-U\end{array}$ & $\begin{array}{l}\text { Transparent } \\
\text { spherical } \\
\text { particles }\end{array}$ & Cl- & 1,0 & $\begin{array}{c}0,75 \\
- \\
0,95\end{array}$ & 1,5 \\
\hline 5 & $\begin{array}{l}\mathrm{AV}- \\
17-8\end{array}$ & $\begin{array}{c}\text { Yellow } \\
\text { spherical } \\
\text { particles }\end{array}$ & Cl- & 1,15 & $\begin{array}{c}0,31 \\
- \\
1,25\end{array}$ & 1,7 \\
\hline
\end{tabular}

\section{Results and discussion}

The amounts of sorbed and desorbed tungstate ions on different anionites are presented on Figure 1.

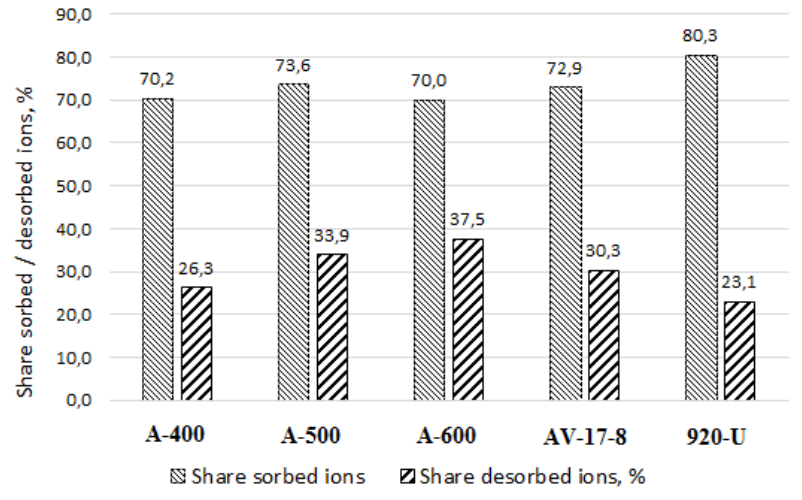

Fig. 1. Distribution of sorbed and desorbed tungsten ions on different anionites.

The percentages of sorbed and desorbed carbonate ions on different anionites are depicted in Figure 2.

The sorption of carbonate and tungsten ions from the clarified concentrated solution was examined after autoclaving with soda digestion.

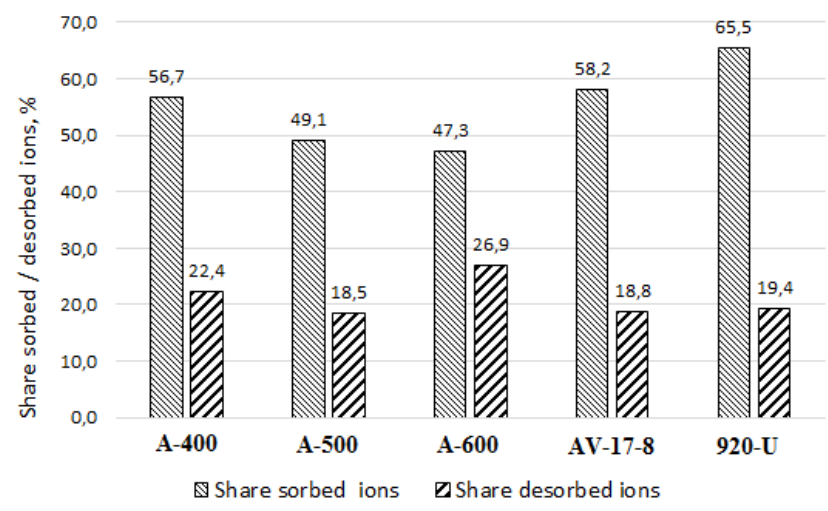

Fig. 2. Distribution of sorbed and desorbed carbonate ions on different anionites.

AV-17-8 anionite comprising the benzyltrimethylammonium ionogenic group was employed as the ion-exchange resin. This anionite was chosen as a high-grade reagent that has high static and dynamic exchange capacities.

The anionite was rendered into the chloride form by reaction with a $10 \%$ solution of ammonium chloride.

A total of three sorption-desorption cycles were performed. In each experiment, the tungsten-containing solution volume was $100 \mathrm{~mL}$, the ionite weight was $15 \mathrm{~g}$, and the ionite volume was $25 \mathrm{~mL}$. The propagation velocity of the solution through the ionite was 1 drop per $3 \mathrm{sec}$, and the propagation of the solution through one column volume was $45 \mathrm{~min}$. A $2 \mathrm{~mol} / \mathrm{L}$ ammonium chloride solution $(100 \mathrm{~mL})$ was used as the desorbent.

Forty percent of tungstate ions are sorbed from the concentrated sodium tungstate solution in the $1^{\text {st }}$ cycle, $38 \%$ in the $2^{\text {nd }}$ cycle, and $32 \%$ in the $3^{\mathrm{d}}$ cycle. Due to the high concentration, the tungstate ion is unable to be sorbed fully on the resin under the specified conditions. The decreased velocity makes the sorption process limiting; therefore, the ion exchange should be performed in dilute solutions. 
The difference in tungstate ions sorption in the three cycles is negligible (Figure 3).

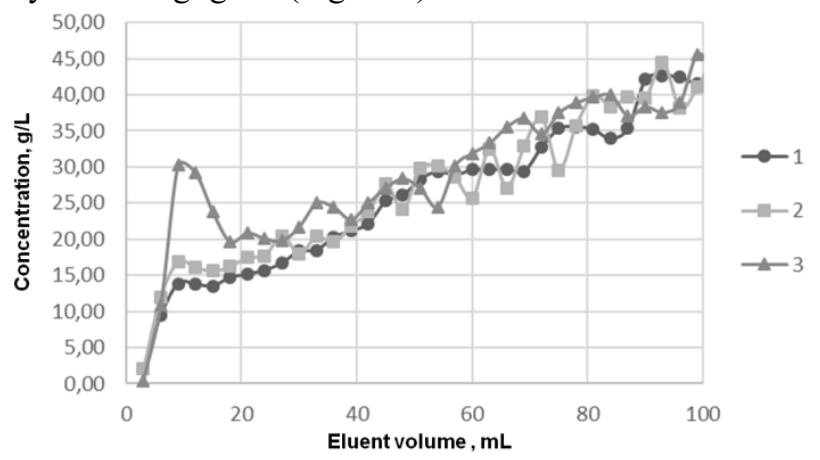

Fig. 3. Tungsten concentration in the eluate after sorption plotted against eluent volume for three cycles; 1 - in the $1^{\text {st }}$ cycle, 2 - in the $2^{\text {nd }}$ cycle, 3 - in the $3^{\text {d }}$ cycle.

The dynamic capacity of the anionite against tungsten diminishes: $320 \mathrm{~g}$ eq/L for the first sorption cycle, $278 \mathrm{~g} \mathrm{eq} / \mathrm{L}$ for the second, and $237 \mathrm{~g} \mathrm{eq} / \mathrm{L}$ for the third. This phenomenon is explained by incomplete desorption. Desorption against tungsten is $100 \%$ in the first cycle and only $70 \%$ in the second. The third cycle shows again 100\% desorption against tungsten, but because the resin capacity decreases with each cycle, carbonate ions fill the space of tungstate ions in the resin matrix.

Desorption of tungstate ions is considerably distinct in each of the cycles. Desorption is uniform in the first cycle, whereas the ions are desorbed chiefly with first portions of the eluent in the second and third cycles (Fig. 4).

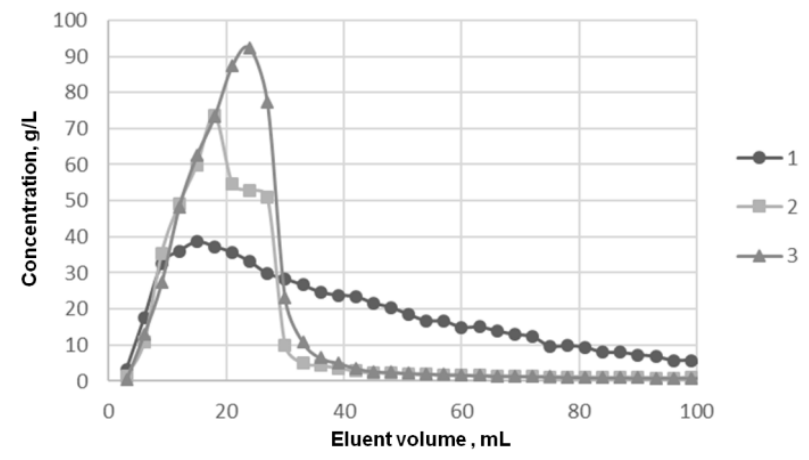

Fig. 4. Tungsten concentration in the eluate after desorption plotted against eluent volume for three cycles; 1 - in the $1^{\text {st }}$ cycle, 2 - in the $2^{\text {nd }}$ cycle, 3 - in the $3^{\text {d }}$ cycle.

The sorption of carbonate ions differs from that of tungstate ions. For instance, the sorption capacity of the resin against the carbonate ion declines in the third cycle, and the resin does not nearly absorb carbonate ions (Fig. $5)$.

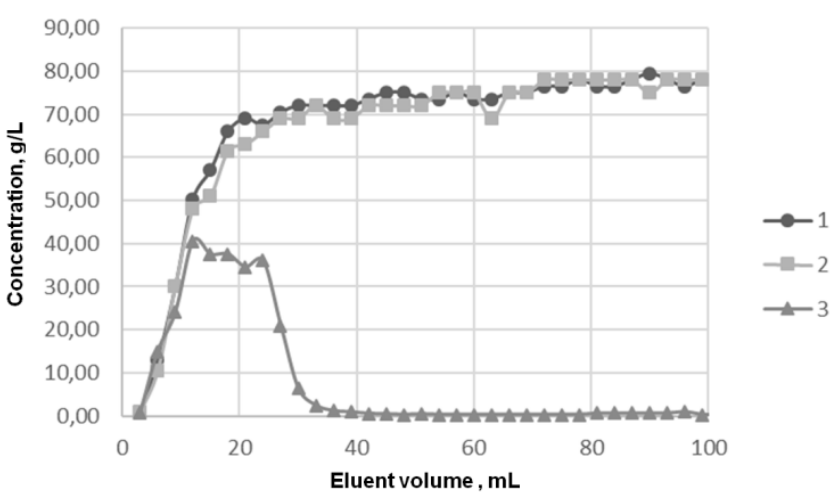

Fig. 5. Carbonate ion concentration in the eluate after sorption plotted against eluent volume for three cycles; 1 - in the $1^{\text {st }}$ cycle, 2 - in the $2^{\text {nd }}$ cycle, 3 - in the $3^{\mathrm{d}}$ cycle.

Desorption profile for carbonate ions follows that of tungstate ions (Fig. 6). Desorption is observed to be more uniform in the first cycle, while it is jump-like in the third cycle.

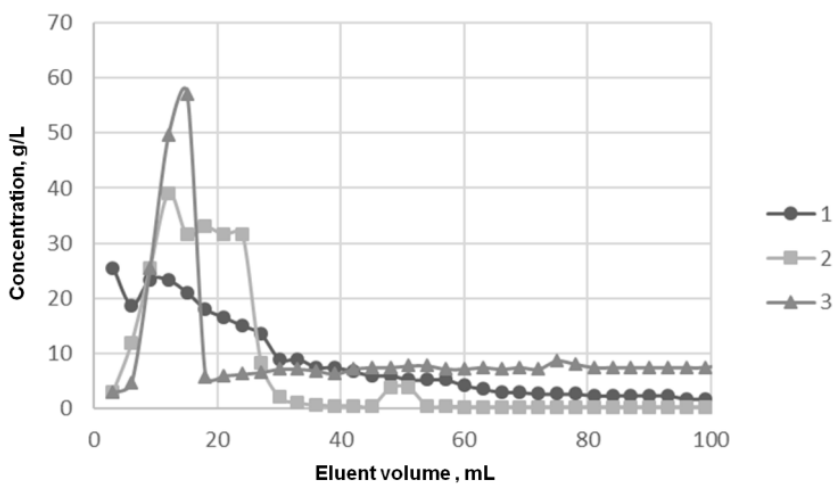

Fig. 6. Carbonate ion concentration in the eluate after desorption plotted against eluent volume for three cycles; 1 - in the $1^{\text {st }}$ cycle, 2 - in the $2^{\text {nd }}$ cycle, 3 - in the $3^{\mathrm{d}}$ cycle.

The anionite capacities against the carbonate ion in the first two cycles do not differ and are $184 \mathrm{~g} \mathrm{eq} / \mathrm{L}$; the capacity in the third cycle is only $73 \mathrm{~g}$ eq/ $\mathrm{L}$ of the initial. The carbonate ions are presumably converted into hydrocarbonate ions which cannot be desorbed with ammonium chloride. In turn, the hydrocarbonate ions take up the place of the mobile ions in the resin matrix and do not allow the sorption of both tungstate ions and carbonate ions.

\section{Conclusion}

It can be concluded from the findings that the sorption of the tungstate ions from the solution on the AV-17-8 resin in the first sorption cycle after autoclave-soda digestion is $40 \%$; however, the anionite capacity then diminishes due to incomplete desorption of the carbonate ions that are also presented in the tungsten-containing solution.

The AV-17-8 resin is not fit for multiple sorption. For effective use of the AV-17-8 resin and effective sorption of all the tungstate ions, the concentration of the target component in the initial solution should be decreased by water dilution. 
This research was conducted with support from the Russian Federation Government (Russian Ministry of Education and Science), contract No. 02.G25.31.0118.

\section{References}

1. V.P. Reva, D.V. Onishchenko, V.A. Kim, V.V. Petrov, A.I. Evstigneev, Refract. Ind. Ceram+ 54, 295 (2013)

2. J. Wilden, V.E. Drescher, M. Schütze, R. Durham, Materialwissenschaft und Werkstofftechnik 41, 608 (2010)

3. J. Matějíček, B. Nevrlá, M. Vilémová, H. Boldyryeva, Nukleonika 60, 267 (2015).

4. A.N. Zelikman, Metallurgiya Vol'frama i Molibdena [Metallurgy of Tungsten and Molybdenum] (Metallurgizdat, Moscow, 1949) (in Russian)

5. N. Holstein, W. Krauss, J. Konys, Fusion Eng. Des. 86, 1611 (2011)

6. A.S. Sánchez, A. Krzemień, P.R. Fernández, F.J. Iglesias Rodríguez, F.S. Lasheras, F. Javierde Cos Juez, Resources Policy 46, 177 (2015)

7. S.S. Bel'skiy, O.E. Bel'skaya, Vol'fram - Proizvodstvo i Potrebleniye [Tungsten - Production and Consumption] in Proc. of $3^{d}$ Inter. Science and Technology Conference "Metallurgy of Light and Refractory Metals" (Ural Federal University, Yekaterinburg, 2014) (in Russian)

8. N.I. Novikov, V.A. Salikhov, Vestnik Tomskogo Gosudarstvennogo Universiteta. Ekonomika 2, 138 (2015) (in Russian)

9. I.A. Rodionova, Makrogeographiya Promyshlennosty Mira: Uchebnik [Macrogeography of the World Industry: Textbook] (Moskovskiy Litsei, Moscow, 2000) (in Russian)

10. C.J. Smithells, Tungsten: A Treatise on Its Metallurgy, Properties and Applications, 3rd ed. (Chapman and Hall Ltd., London, 1952)

11. A.N. D'yachenko, S.I. Ivankov, R.I. Kraidenko, A.B. Manucharyants, D.G. Petkevich-Sochnov, G.S. Spitsin, Yu.V. Perederin, A.G. Karpov, V.Yu. Yegorov, Polzunovskiy Vestnik 2, 120 (2015) (in Russian)

12. A.I. Nikolaev, V.G. Maiorov, V.K. Kopkov, Russ. J. Appl. Chem+ 70, 521 (1997)

13. A.N. Zelikman, G.A. Meerson, Metallurgiya Redkikh Metallov [Metallurgy of Rare Metals], (Metallurgiya, Moscow, 1973) (in Russian)

14. A.S. Medvedev, Vyshchelachivaniye i Sposoby Ego Intensifikatsii [Leaching and Its Intensification Methods] (MISIS, Moscow, 2005) (in Russian)

15. S.S. Bel'skiy, Vestnik Irkutskogo Gosudarstvennogo Tekhnicheskogo Universiteta 12, 204 (2015) (in Russian)

16. E.I. Kurchenko, Chemical Concentration of Lowgrade Tungsten-containing Industrial Waste Discharge in Proc. of Inter. Symposium "Inorganic Fluorides: Chemistry and Technology" (TPU Publishing House, Tomsk, 2014)

17. H.I.V. Vidales, A. Jiménez-González, Green Process. Synth. 4, 167 (2015)

18. A.N. D'yachenko, A.P. Dugel'nyi, R.I. Kraidenko, S.N. Chegrintsev, Izvestiya Tomskogo
Politekhnicheskogo Universiteta 322, 62 (2013) (in Russian)

19. R.I. Kraidenko, Yu.V. Perederin, D.S. Filatov, A.B. Manucharyants, A.G. Karpov, M.S. Vasilishin, Polzunovskiy Vestnik 2, 135 (2015) (in Russian)

20. Y.G. Choi, G. Sakai, K. Shimanoe, N. Miura, N. Yamazoe, Sensor Actuat B-Chem. 87, 63 (2002)

21. V.S. Yu, S. Nakai, A. Ali, The analyst 131, 434 (2006)

22. A.G. Kholmogorov, V.P. Kyrillova, O.N. Kononova, S.V. Kachin, O.P. Kalyakina, G.L. Pashkov, Hydrometallurgy 53, 177 (1999)

23. A.G. Coedo, T.D. Lopez, F. Alguacil, Anal. Chim. Acta 315, 331 (1995)

24. GOST (Russian State Standard) Nos. 20301-74, 13504-68, 5.1342-72: Smoly Ionobmennyye. Anionity [Ion Exchange Resins. Anionites] (Izdatel'stvo Standartov, Moscow, 1992) 